\title{
God our king
}

\author{
Jan Muis (Protestant Theological University Utrecht) ${ }^{1}$ \\ Research Associate: Department of Dogmatics and Christian Ethics
}

University of Pretoria

\begin{abstract}
This article discusses whether the metaphor of "king" can still be used in Christian God-talk. Firstly, it is argued that the "king" metaphor for God is an indispensable key metaphor in both the Old and the New Testament. "King" has become a root metaphor in the canonical text of the Old Testament and Jesus' proclamation of the coming kingdom of God presupposes that God is king. Secondly, the Biblical meanings of the metaphor are explored. God's kingship implies his authority and power to fight the forces of evil, to liberate and lead his people and to control the events of history. Modified by Jesus Christ, God's kingship is universal, non-violent and in accordance with his love. Then, the use of the metaphor in contemporary God-talk is considered. Because "king" is the only metaphor that can give expression to God's ultimate highness and authority, it cannot be replaced by others. In the concluding section the "king" metaphor for God is conceptually explained in terms of the relationship, the agency and the power of God it implies.
\end{abstract}

\section{INTRODUCTION}

These days, the question is asked whether the image of king can still be used to talk about God. Modern people only know kings from fairy tales or ancient histories. If they happen to live in a kingdom, as the British and Dutch people do, they know their queen as a ceremonial figure who merely symbolizes the unity of the people or the nation; she has no or very limited power, delegated to her by the people. The activity of the queen does not influence their lives. Calling God a king in this sense, would reduce him to a distant, irrelevant ornament in our lives. On the other hand, the traditional understanding of God's kingship implied that God completely dominated people's personal lives and history as a whole. He was the ultimate ruler above all earthly kings, peoples and nations, who determined and directed all their particular actions.

\footnotetext{
${ }^{1}$ Prof dr J Muis is Professor at the Protestant Theological University Utrecht (The Netherlands) and a member of the International Advisory Board of HTS Theological Studies. $\mathrm{He}$ is a research associate of Prof Dr Johan Buitendag, Department of Dogmatics and Christian Ethics, University of Pretoria.
} 


\section{God our King}

This traditional image of God as king seems even more inappropriate to modern people. It depicts God as a distant being beyond our reach who denies us our freedom, and with whom we cannot have a personal relationship. It is hard to imagine the love of such a God. It is for this reason that some conclude that "king" can no longer be used as a metaphor to understand our relation with God (Berkhof 1993:216; McFague 1987:63-69).

However, when we do away with the metaphor of "king", we run the risk of severing contemporary Christian God-talk from its origin in Scripture. Key metaphors for God in the Biblical witness fix the referent of Christian God-talk; they determine what Christians talk about when they talk about God. (Ricoeur 1977:301; Van Huyssteen 1997:135, 138, 139). If "king" is one of the Biblical key metaphors, then it is essential to a God-talk that is grounded in the Biblical witness. Moreover, if "king" is a Biblical key metaphor, it not only identifies, but also indirectly describes the God of the Bible (Soskice 1985:158, 159).

Contrary to what many modern theologians believe, there are good reasons to maintain that metaphorical language can be descriptive. "Metaphor" can be defined as a way of talking about something in terms normally used to talk about something else (Soskice 1985:15, 49). When a metaphorical utterance creates a metaphorical statement with a metaphorical meaning which can be understood by others, it is descriptive. Metaphorical talk about God is not, as Sallie McFague argues, necessarily a mere redescription of our existence in this world in relation to God (McFague 1982:133-137). Janet Soskice (1985:132-141) has convincingly argued that it can depict the reality of God himself in a way analogous to the way scientific, theoretical models describe invisible physical reality which, apart from these models, is not accessible. When a metaphorical description of God is generally accepted by the community of faith over time, it is not just a possible guess or a "likely account" (McFague 1987:33, 35, 39); rather it is believed that God in a sense really is as he is indirectly described by the metaphor.

In this article, I will argue that "king" is an indispensable key metaphor in contemporary Christian God-talk. A key metaphor is a metaphor with many implications; it can be used as a model which illuminates our understanding of God and guides our Christian life (McFague 1982:141, 142; Soskice 1985:112; Brümmer 1993:26). I do not, however, claim that "king" is the central metaphor for God. The Old Testament contains diverse basic metaphors for God (Brueggemann 1997:231, 232; Rendtorff 2001:181, 193). The language of faith is not based on one central model such as Father (pace Soskice 1985:112), nor is it the task of systematic theology to develop just one comprehensive key model of the relation between God and human beings 
(see Brümmer 1993:20, 21). Both in the language of faith and in systematictheological reflection different key metaphors play an indispensable role, just as they do in the bible.

In the next section, I shall first argue that the metaphor of king is an indispensable key metaphor in the Biblical witness about God. In the third section, I shall further explore the use of the metaphor of king in the Old and New Testaments. Its Biblical meaning(s) might be quite different from both the modern experience of human kingship and the traditional theological explanation of God's kingship, and it might express something about God that other metaphors do not express. This would be a reason for its continued use in contemporary God-talk, despite the fact that real kingship has become an obsolete phenomenon in human society. It is by no means easy to establish the Biblical meaning of the metaphor because it assumes different functions and meanings in diverse texts and contexts. Although it is not possible to deduce a so-called Biblical concept or doctrine of God's kingship from the diverse Biblical texts (Barr 1996:206-219; Brümmer 1993:30, 31), I shall try to sketch the main elements of its Biblical meaning(s).

In the fourth section, I shall consider whether the meaning of the Biblical metaphor of king can be expressed by other metaphors and would try to determine which elements of this metaphor are essential for Christian Godtalk and which have become irrelevant. In the concluding section, I shall try to conceptually describe in what sense God could be understood to be like a king. A conceptual account is necessary because believers use the word "king" for God in situations in which specific events are experienced as signs of the presence or absence of God's kingly rule. It should be possible to critically ask whether such an event confirms or contradicts God's kingly rule. A conceptual explanation of God's kingship can help us to decide whether the use of the word "king" in a particular situation is justified. Another reason why conceptual explanation is needed is that Christian believers should be able to explain what they mean when they talk about God as king to others who are not familiar with this idiom. I shall try to explain the metaphor of king in terms of the relationship, the agency and the attributes of God it implies or presupposes.

Thus far, I have only dealt with the metaphor of king. In the following argument, I shall also deal with God's kingship, which is a different concept. How the metaphor of "king" can be used to talk about God, is purely a linguistic matter: which associations of this term are appropriate when talking about God, and which are not? In this approach, the question of whether God himself can really be likened to a king remains open. By contrast, when we talk about God's kingship, we assume that God really is like a king and that 


\section{God our King}

there are similarities and differences between divine kingship and human kingship. In this case, the question arises which characteristics of human kings can and which cannot be attributed to God. This question is not restricted to language; it is based on the realistic assumption that God really is as he is metaphorically described. If we claim that a metaphorical description of God cannot be cognitive (so McFague 1987:39, 196), the second question becomes superfluous and senseless. If we accept the metaphor of king as a true metaphorical description of God, we can also realistically talk about God's kingship. The starting point of this paper is the problematic metaphor of king, but I have taken the liberty of also dealing with God's kingship, because the metaphor of king is used with a realistic claim in the Biblical texts and in the Christian tradition.

\section{2. "KING" AS A BIBLICAL KEY METAPHOR FOR GOD}

\subsection{The New Testament}

As Christian belief is shaped by the Christ-event, it is appropriate to start our investigation in the New Testament. At first, the "king" metaphor for God seems to play a very limited role here. It is not God, but Jesus who is predominantly called king. Besides the term "king", we find the messianic title Christ and the title Kyrios, which express his authority. In the letters, God is only occasionally ( 1 Th 1:17; 6:15; Rv 15:3) called king and the term kingdom of God is only used as a conventional stereotype (Rm 14:17; 1 Cor 4:20; 6:9; 15:50; GI 5:21; Eph 5:5; Col 4:11; 1 Th 2:12; 2 Th 1:5). For Paul, the justice of God (Jüngel 1972:263-268; Barth 1976:435; Childs 1996:644) and the Spirit (Dunn 1998:191) instead of the kingdom of God have become key terms to refer to God's saving agency in Jesus Christ. In the Gospels, Jesus only once (Mt 5:35) explicitly called God king and in the parables (Mt 18:23; 22:2, 7, 11, 13) he only indirectly calls God king. Jesus did not call God by the name of "king", but by the name of "Father" (Theissen 2001:51), which has become the central word for God in the New Testament and in the creeds. This name has led to further reflection on the unique relation between the Father and the Son, which eventually resulted in the church's adoption of the Trinitarian dogma. Jesus does not speak about God as king, but he does speak about "the kingdom of God", the central term of his proclamation and ministry.

That the term "king" is reserved for Jesus and the word "father" has replaced the term "king" as the central name for God, might lead to the conclusion that the word "king" is no longer a key term for God in the New Testament. However, I believe this would be wrong for two reasons. Firstly, although Jesus' kingship is at the center of the New Testament witness, it 
does not replace God's kingship. God has not transferred his kingship to Jesus in such a way that he himself ceased to be king. Rather, God and Jesus are both king (cf Eph 5:5), which means that God shares his kingship with the risen Lord (Barth 1976:431-435). God's kingship has not been transferred to Jesus, but its exercise has been modified (Van Ruler 1974:89, 90). From here on, God reigns together with Jesus and therefore in the way of Jesus. His rule has not ended, but the mode of his reign has changed. Secondly, the proclamation of Jesus as king in the letters does not replace Jesus' proclamation of the kingdom in the gospels. It is an important fact that the early Christian church has preserved and transmitted the gospel of the coming kingdom in the gospels, which were written after the letters. This means that the expectation of the coming kingdom of God remains important for them who believe in the risen, present king, Jesus Christ (Moltmann 1997:199, 200).

Let us now have a closer look at Jesus' proclamation of the coming kingdom of God. Jesus proclaims the kingdom by his teaching, his deeds and especially through his parables. He depicts the kingdom as an activity or as a state or area, be it future or present. It is impossible to deduce a single concept of the kingdom from the diverse texts (Barth 1976:407). Be that as it may, it is an eschatological reality, which means that it is "coming". It would be wrong to conclude from the coming of the kingdom that God's kingship lies in the future, or even, if God's being God is identified with God's being king, that God is not yet fully God (see the careful reflections on the future of God himself in Moltmann 1995:40, 41, 364). God's kingship does not depend on God's kingdom; God's kingdom depends on God's kingship. Jesus proclaims the coming of the kingdom as the coming of God as the king who himself will create his kingdom of justice and peace (Barth 1976:404-411). Some later parts of the Old Testament also indicate that God can be confessed as king, regardless of the fact that his kingdom still lies in the future (see sec 2.2). Thus, Jesus' proclamation of the coming kingdom does not deny, but presuppose that God is already king.

Opposite hermeneutical and systematic conclusions are drawn from the remarkable fact that Jesus proclaims the kingdom, but hardly calls his God king. Sallie McFague, for instance, proposes a metaphorical theology of the kingdom of God and at the same time rejects "king" as a model of God on the basis of this kingdom (McFague 1982:17-19; 42-54; 108-111; McFague 1987:63-69). In her view, the "king" metaphor for God is not central to Jesus' proclamation of the kingdom of God (cf Theissen 2001:51). She separates God's kingdom from God's kingship, neglects its eschatological character and reduces it to a present "mode of being in the world" (McFague 1982:109). 


\section{God our King}

However, the expression "kingdom of God" which Jesus chose as the central term for his proclamation and which was common in his Jewish tradition, implied an understanding of God as king. Moreover, the eschatological character of God's kingdom implies that its realization depends ultimately on God's kingship (see sec 3.2). Therefore, it would be meaningless for us to call a life in happiness, peace, and salvation the "kingdom of God" if we could no longer talk about God as king. "Kingdom" cannot be a useful metaphor if "kingship" is not. The one cannot exist without the other.

In contrast with McFague, Wilfried Härle argues that God's coming kingdom implies God's kingship. According to Härle (1999:17), Jesus' proclamation of God's kingly reign is his way of talking about the reality and agency of God. As a consequence, he analyzes the proclamation of the coming kingdom as an implicit doctrine of God. In Jesus and his proclamation of the kingdom, the reality of God is present in our time and on our earth. Kingdom means rule of God, and rule is not just an act of God besides others. Being God is to rule as a king (cf Schillebeeckx 1982:166; Lindemann 1986:206). Thus, Härle identifies God's kingship with his being God. He discovers four fundamental tensions or polarities in Jesus' proclamation: between the ordinary and the extraordinary, between high and low, between the sovereign coming of the kingdom and the call to freely enter it, and between its presence and future (Härle 1999:19-24). These polarities imply attributes of God such as power and freedom. Other attributes are excluded: impassibility, because it denies that God humiliates God self in Jesus unto death, and predetermination, because it denies the constitutive role of faith in the realization of the kingdom. However, whether a full description of God can be derived from Jesus' proclamation of the kingdom has to be doubted. Härle proposes "love" as the central term in such a description (Härle 1999:29), but he does not explain how this term is implied by the kingdom of God.

Furthermore, it is incorrect to identify God's reign with God's agency as such. Other acts of God, such as creating, blessing, caring and saving cannot be subsumed to ruling. In Härle's approach, kingship becomes the only model for God from which the complete doctrine of God is to be derived. Kingship, though, is not the central theological concept (Barth 1937:976, 980); it is one of the key models and needs to be complemented by others.

Despite these criticisms, we must recognize that Härle rightly points to the connection between Jesus' proclamation of the kingdom and the kingship of God. This connection is particularly clear in the Lord's Prayer. Jesus Christ has taught his disciples to pray to his Father in heaven: "your kingdom come". In the later tradition, "yours is the kingdom", was added to the original version which addition excludes the idea of God still having to become a king in the 
future. One cannot ask God for the coming of his kingdom without acknowledging that God is already king (Mettinger 2005:92). This is a compelling reason for not removing the metaphor of king from Christian Godtalk. Discarding the Lord's Prayer is no option for Christians. The practice of the Lord's Prayer implies the recognition of God as king.

This does not mean that the content of God's kingship can simply be deduced from the Lord's Prayer or from Jesus' parables. I would rather say that Jesus' proclamation of the kingdom presupposes God's kingship as it was commonly believed by Jews in his time in continuity with the Old Testament. This leads us to the Old Testament witness about God's kingship.

\subsection{The Old Testament}

The name "king" for YHWH occurs mainly in hymns in the Psalter and in poetic texts in the prophets; in many parts of the Old Testament it is not prominent or is absent (Mettinger 2005:116). It only became a central theological notion in circles in Jerusalem around the temple (Dietrich $1980: 251,259)$. This raises the question of whether this metaphor is indispensable for understanding the Old Testament witness about God. This question has often been answered by referring to the origins of Israel's faith. Von Rad $(1964: 568,569)$, for instance, thinks that the image of God as king is not original and therefore not central. By contrast, Buber (1936:73-79) regards it as original and therefore the central model of God. However, "originality" and "indispensability" are different issues. Originality is not a sufficient or necessary condition for indispensability. It is possible for an image to be indispensable, although not original; it is also possible that an image is original, but not indispensable. The question of origin is about the history of Israel's religion; the question of indispensability is about the text as a whole in its canonical shape. Therefore, these questions must be separately discussed. Let us first briefly consider the question of the origin and development of the idea of God's kingship.

It is generally held that the belief in YHWH as king does not reflect human kingship in Israel (Dietrich 1980:254; Mettinger 2005:93), although there are exceptions to this consensus opinion (Härle 1999:14; Von Rad 1964:568). The belief in YHWH preceded the time of the kings. What it meant in those days remains hypothetical. Martin Buber sought the origin of God's kingship in the Sinai-covenant and thought that melek originally meant the leader of the nomadic tribes. He strongly contrasted the melek-god of history with the baal-god of the field and the soil. According to Buber (1936:65-69, 8286) melek has the same meaning as the name YHWH: to God's people, God is present in their history. According to this view, God is king even if there is 


\section{God our King}

no place or territory which constitutes God's kingdom: to be king is to lead one's people into their future. This historical reconstruction, which has deeply influenced systematic theologians such as Miskotte $(1971: 98,131)$ and Moltmann $(1997: 86,87,197)$, is not considered to be a plausible theory on the origin of the idea of YHWH as king (Von Rad 1964:570; Dietrich 1980:253; Zenger 1986:177, 177). Israel had probably, taken the epithet "king" from Canaanite religion and applied it to $\mathrm{YHWH}$ in the context of its own belief, by which the function and the meaning of the term had changed profoundly (Dietrich 1980:254, 255; Mettinger 2005:95, 96). In the Psalms about God as king and in Isaiah and Deutero-Isaiah the theme of God's kingship is fully developed. Here it becomes a root metaphor, that is, a comprehensive model to understand all there is (Mettinger 2005:92). It is remarkable that the metaphor of king did not disappear when Israel had no kings. During exile and after the return from exile it became increasingly important (Dietrich 1980:263267; Mettinger 2005:151).

In trying to answer the second question pertaining to whether the metaphor of king is indispensable in the canonical Old Testament witness about God, three points should be considered. Firstly, Mettinger has shown that the deep structure of the Canaanite myth of divine kingship (see sec 3.1) has shaped the Old Testament stories about creation, Exodus, mount Zion, and the day of the Lord. Thus, the image of God as king has become dominant in diverse texts and contexts and is central to an understanding of God's history with Israel and the world (Mettinger 2005:100-115).

Secondly, after the exile the idea of God's kingship dominated Israel's belief, although the way in which it is understood in the later stages of the tradition, differs. In the tradition of Chronicles and Ezra, God is seen as the present king of Israel who rules by the torah. In the eschatological tradition God's universal kingdom, in which all the nations will acknowledge God as king, is expected in the future (Dietrich 1980:267). In the apocalyptic tradition, God's kingdom is present as a heavenly, hidden reality, which will be revealed universally at the end of times (Härle 1999:16; cf Ladd 1962:234). The centrality of the belief in God as king in later parts of the Old Testament is confirmed by the fact that king became the name by which to address God in Judaism, in continuity with some Psalms (Rendtorff 2001:181, 184).

Thirdly, Exodus 15:18 does not prove that the idea of God's kingship stemmed from the Mosaic period, as Buber $(1936: 119,130)$ and Barth (1939:678; 1950:176) thought. Seen from a canonical perspective, this text however shows how the compilers of the old traditions about the Exodus intended this tradition to be heard as a witness to God's sovereignty from the beginning (Childs 1998:634). 
It is my view that these considerations justify the claim that in the canonical text of the Old Testament, "king" is an indispensable key metaphor for God, although it has not been equally important at all times, places, and in all traditions and God's kingship has been understood in very different ways.

\section{THE MEANING OF GOD'S KINGSHIP IN THE BIBLICAL WITNESS}

\subsection{The Old Testament}

Because the Old Testament witness of God's kingship is the presupposition of Jesus' proclamation of the kingdom and Jesus' kingship has not replaced God's kingship, it is appropriate to start our exploration of the Biblical meaning of God's kingship in the Old Testament. God's kingship cannot be understood simply by taking a human form of kingship in the Old Testament as a model of God. Different forms of human kingship appear in the Old Testament: kings of a city-state, kings of a people or nation, kings of empires with different peoples and nations. A king could be the leader of a temporary army without having a throne and a palace (Saul), or could be a ruler who controls an empire with a big administration and bureaucracy (Solomon). Therefore, the meanings of YHWH's kingship should be inferred from diverse texts in different contexts. Dietrich and Mettinger undertook this study in different ways. Dietrich's leading question is whether the epithet "king" has changed Israel's understanding of YHWH's character (Dietrich 1980:252). His results are as follows: The term "king" as a divine name has been taken from the Canaanites. YHWH is named king, because he replaced El in the Canaanite pantheon: He is the king of the other gods, the king in heaven. Originally, his throne was the ark, which is the moving place of his presence in the war against Israel's enemies. David then initiates, at least partially in his own political interests, the cult of YHWH in the temple on mount Zion, where YHWH sits on the royal throne as king of Jerusalem. In a vision, Isaiah sees the king in his holiness on his throne in heaven above the temple and Zion (Is 6). The second Isaiah proclaims the king of Israel as Savior and Liberator of his people. After the exile, two understandings of YHWH's kingship emerge, a nationalistic and a universal one. In Chronicles, it is said that king Solomon was sitting on the throne of YHWH (1 Chr 17:14; 28:5; 29; 23; 2 Chr 9:8), which suggests that the state Israel as such is the kingdom of YHWH (cf Zenger 1986:186). In the eschatological tradition, God's kingship means that YHWH rules and will judge the nations. Dietrich $(1980: 263,268)$ concludes that the epithet "king" has not changed the essence of YHWH as the God who liberates his people. YHWH is not a despot who serves his own interests, but 


\section{God our King}

uses his power for his people. This means that $\mathrm{YHWH}$ is king on his own terms and that his kingship can only be understood as a specific, "jahwistic" kingship.

Mettinger (2005:96) adopts a somewhat different approach. He understands YHWH's kingship against the backdrop of the Canaanite myth about El and Baal, which is used by Israel to confess $\mathrm{YHWH}$. Israel borrows from this myth its underlying conceptual structure which contains three elements: 1.) God asserts God's kingship; 2.) God defeats the powers of chaos; 3.) the temple is the sign of his power and authority. The essence of this kingship is warring against chaos; the powers of chaos are concrete enemies in history. Thus, in Israel, the Canaanite myth is historized and eschatologized. The image of $\mathrm{YHWH}$ as warring against the powers of chaos can be found in texts about creation, mount Zion, the Exodus, and the Day of the Lord. These texts show that God has become king in the act of creation and re-establishes his authority in history again and again by defeating the powers of chaos and evil until his ultimate victory on the last day. There has never been a time when God was not king. Because of God being king, God is the Highest One. This imagery of a battle is connected with the imagery of the Lord of host, who sits on his throne in the temple of Jerusalem (Mettinger 2005:123-157). The temple is God's palace and part of the heavenly reality. YHWH reigns in God's heavenly palace, and God acts in the history of Israel and that of the nations. God leads history to the goal God has chosen.

Because of God's majestic rule, God is the holy One and the only One. In the Old Testament the images of warring and ruling cannot be separated, but there is a tension between the two. The first is dynamic, the second is static. The first suggests that God becomes king by creating peace and justice on earth by defeating his enemies, the second suggests that God is permanently king on a heavenly throne from where God rules history.

On the basis of the explorations of Dietrich and Mettinger, some general characteristics of God's kingship according to the Old Testament can be described. As king, God is related to his people Israel and to all the nations. This is a "vertical" relation: God is above anything else in authority and power. God is free to decide and to act in order to achieve God's purposes. But this relation also has a "horizontal", historical aspect: God leads God's people as a shepherd to its future of peace and justice. In this sense God is proceeding to God's kingdom. God is not despotic; God liberates and God rules in justice. God's goal is to achieve justice and peace for God's people and ultimately, for all mankind. God has been king from creation and will be king till the last day. In this sense God is king forever, that is, in all times (Ps 10:16; 146:10; 29:10). Yet, God's kingdom, the life, peace and 
justice for all peoples and nations, still has to come. This implies that God is not king because God's kingdom is a reality in this world; rather, God's kingdom will be fully realized because God is king. This poses a huge problem to us: what is a king without a kingdom? To conclude that God's full kingship is in the future because his kingdom is in the future is wrong, because it minimizes the Old Testament testimony of God's present kingship. God is already king and at the same time God's kingdom is not yet present and does not manifest itself in this world. Apparently, God's kingship can only be discovered from time to time in special events and experiences and then only provisionally and partially so (Mildenberger 1992:316-327). Most of the time it is hidden in this world. ${ }^{2}$

Although there are instances in which God's judgment and wrath are manifested in violent ways, God's warring and ruling agency is ultimately a saving and liberating one. The combination of warring and ruling shows that God is both in history and above history. God's rule is basically an ordering of creation and history as a place of peace and justice (Brueggemann 1997:238, 272). Several attributes of God, such as highness and exclusiveness, majesty and holiness, justice and mercy, are implied by the Old Testament metaphor of king, but the central attribute is that of power. God's power is primarily the authority to rule and the capacity to act in history according to God's will (Mettinger 2005:136-138; Brueggemann 1997:268, 273). God's power is the power to liberate and to bring justice, and the exercising of it is determined by God's character, God's will, God's purposes, God's mercy and righteousness (Mettinger 2005:150; Brueggemann 1997:272-275).

\subsection{The New Testament}

Our understanding of God's kingship is further qualified by Jesus' proclamation of God's kingdom and by the proclamation of Jesus as king. In Jesus' proclamation of the kingdom, the following points are central to our topic. Firstly, although the understanding of the term "kingdom" in the New Testament as space or area is still defended (e.g. O'Neil 1993), it is now generally accepted that Jesus understands the kingdom as God's active ruling. The kingdom is not something that exists independently of God's agency, only to become God's when God takes possession of it. God's kingdom is eschatological; it is coming to us. It is a reality that God our king brings to us and creates for us (Ladd 1962:236; Moltmann 1997:201, 202; Barth 1976:404, 405). This confirms what we have seen in the Old Testament: God's kingdom depends on God's kingship. This means that only God has the

\footnotetext{
${ }^{2}$ According to Calvin, God's reign is manifested in all that happens in this world and the council of God's will is hidden. However, it is not God's council that is hidden; God's reign is hidden.
} 


\section{God our King}

power to fully realize God's kingdom. God invites people to cooperate with God, but this does not imply that it is their task to realize God's kingdom and that the coming of the kingdom is impossible without them. Secondly, Jesus does not proclaim the kingdom for a particular group or nation. The kingdom of God is not exclusive but inclusive. Lastly, the kingdom Jesus proclaims is not realized by the use of violence against other people (Theissen 2001:53, 54; Childs 1996:638).

Because the New Testament proclaims Jesus as king, we cannot understand properly the way in which God is king apart from Jesus Christ. God's kingship is qualified by the kingship of Jesus Christ in two respects. Firstly, it is the crucified one who is proclaimed as king (Jn 19:33-37). This Lord is the servant (Phlp 2). The Lamb is Lord of lords and King of kings (Rv $17: 14)$. In this paradoxical confession the normal order of this world between king and subject, lord and slave, victory and defeat, life and death is reversed. The power with which Jesus rules is the power by which he has suffered and died for others. The power to suffer and to die for others is love; the power to suffer and die for one's enemies is ultimate, divine, perfect love. That God's kingship has been qualified by the kingship of the suffering and dying servant means that the power of God cannot contradict the love of Jesus. This power is indeed often hidden in human life and in the history of this world. The crucified is risen and exalted in heaven and his kingship is hidden in this world (Van Ruler 1974:105). Secondly, the fact that God has realized and manifested God's kingship in the life, death and resurrection of Jesus Christ implies that there is no place on earth, no throne, no palace, no nation, no state, no army, no temple, no church where God's presence as king is as real as it is in Jesus Christ. Long ago, a believer in Jerusalem could have taken the temple quite literally as the palace of $\mathrm{YHWH}$ and could have identified the kingdom of God with the state of Judea, but this is no longer possible, because God rules together with Jesus Christ and Christ is in heaven. As a consequence, in New Testament and Christian God-talk "throne" and "temple" have become metaphors for the presence and agency of Christ and of the Spirit.

\section{THE METAPHOR OF "KING" IN COMTEMPORARY GOD- TALK}

"King" is an indispensable key metaphor in Biblical God-talk, but the Bible uses other key metaphors as well to describe God. Different metaphors highlight different characteristics of God. This is also the case in contemporary God-talk. "King" cannot be our central metaphor for God. One of the reasons for this is that this metaphor is not appropriate to express the love between God and man. Human kings do not love their subjects, nor do human beings 
love their king, whatever emotional bond there might occasionally be between them. Kingship is not even a personal relationship, but an official one. Therefore, the metaphor of "king" can only be used together with other traditional and modern key metaphors for God, such as "shepherd", "father", "judge", "lover", and "friend".

Moreover, when the metaphor of king is used in contemporary Christian God-talk, some of its Biblical meanings no longer are relevant. A visible throne and temple on earth are not necessary for God's rule. This can already be seen in the later parts of the Old Testament: YHWH was proclaimed as king by the second Isaiah at a time when there was no temple. In addition, for Christians God's reign is the reign of Christ and the Spirit. The defeat and physical destruction of the enemies of God's people as a means to give effect to God's kingship have been superseded by Jesus' proclamation of the kingdom and the realization and manifestation of God's kingship on his cross and in his resurrection. Powers of evil and chaos still exist. A battle is raging between God and God's enemies, and these will have been defeated in God's kingdom. But in this battle no physical violence is exercised against people. Therefore, the "king" metaphor for God, as it is used in Christian Godtalk, does not imply that God uses physical violence. ${ }^{3}$

The metaphor "king" above all expresses God's ultimate authority. To be king is to have authority over others. God is the king of kings (Dn 2:37; Rv 19:16). God's authority has not been delegated to him (Van Gennep 1989:420). There can be no authority above God's; otherwise God would not be God. God is the highest One. In the Bible, God's authority is described as God's right to command and to judge. Authority is a legal notion; it functions in an order of justice. Therefore God's authority is closely linked with God's justice. Because God is the just king, God has the authority to give us God's law and to demand our obedience. The metaphor of "king" is the only one that can express God's highness and authority. Therefore, it cannot be replaced by other metaphors.

However, the metaphor of "king" could be omitted in Christian God-talk if we could describe God's ultimate authority in a non-metaphorical way, for example by grounding it exclusively in his being creator. This is the traditional account of God's authority. But in this approach God's authority is not intrinsically related to God's coming kingdom, nor is it qualified by the kingship of Jesus. It understands God's authority one-sidedly protologically, and neglects its eschatological character (Noordmans 1979:453-470). God's authority is based on both God being creator and God being king. That is why the metaphor of king cannot be removed from contemporary Christian Godtalk.

\footnotetext{
${ }^{3}$ Whether physical violence is used in God's last judgment is a different question.
} 


\section{God our King}

Thus far, I have only dealt with God's authority. The "king" metaphor for God also implies power. Authority cannot be exercised without some form of power. God's power as king can be generally defined as the way in which God exercises God's authority and realizes God's coming kingdom. In trying to understand this power, we are once again confronted with the tension between God's present kingship and the coming kingdom, which can neither be surpassed in a higher synthesis, nor be removed by denying one of its poles. When one interprets the whole world, as it actually is, as God's kingdom, the power of God means that God is working in all that is happening. This view denies the eschatological, coming character of the kingdom. On the other hand, if we understand "the kingdom of God" as the symbol of the ultimate sense and goal of human life to be realized by human beings, the only power God would have, would be to call human beings, to reveal God's purposes and to wait and see whether or not they will follow him. This view denies the presence and power of God's kingship. If we seriously pray both "your kingdom come" and "yours is the kingdom", both these understandings of God's power are impossible. That God's kingdom still has to come implies that not all that is happening is a result of God's will: there are enemies, powers of chaos and evil fighting against God. That God's kingdom will come implies that the realization of it does not depend on human activity alone: God has the power to realize God's coming kingdom.

\section{CONCEPTUALIZING THE METAPHOR OF KING}

In order to use the metaphor of king adequately in diverse situations of Christian God-talk and to explain it to other people, we need to understand its core meaning. We can explain this meaning by specifying what kind of relationship, what kind of agency and what kind of power the metaphor implies. This conceptual explanation is partial and cannot replace the metaphor itself, because the gain of preciseness at the conceptual level means a loss of the appeal, liveliness and richness of the metaphor as it is used in a specific context. In particular situations of speech a metaphor always means more than what can be described conceptually. To explain the meaning of "Paul is in the evening of his life" by "he is in the later part of his life" is an enormous reduction. The word "evening" in this statement suggests many more things, such as: "his life is getting darker, its colors are becoming less sharp" (these are again metaphorical statements), and: "his life is getting quieter". This metaphor has a specific meaning in the situation in which it is uttered, for instance when it is stated that Paul no longer visits other people. Nevertheless, the fact that Paul is in his later years remains part of any specific, contextual meaning of the metaphorical statement. Although partial, a 
conceptual explanation of the core meaning of the metaphor can be useful. The same applies to the "king" metaphor for God.

The explanation of the metaphor in terms of relationality, agency and attributes is in itself not metaphorical, because relations, acts and attributes are abstract realities. When we apply "concrete" nouns for visible entities in our spatio-temporal world to God, we talk in a metaphoric way about God, because God does not belong to the class these entities belong to. However, love, justice, and power are not material and visible entities; they are abstract, which does not mean that they are not real and cannot be experienced. The attribution of love, justice and power to God would be a metaphorical transfer if God and the entities of this world could in no way have in common the attributes of having love, being just, and having power. Why would that be the case? I see no theological reason why these attributes could not be directly ascribed to both created entities and their Creator.

That the attribution of, for instance, power to God is not a metaphor can also be demonstrated from a linguistic perspective. A metaphor is a statement in which we talk about something by using one or more word(s) normally used to talk about something else. The metaphorical statement becomes a category mistake when interpreted literally. When we take the metaphorical statement "Emily is the sun in our family" literally and conclude from it that the earth rotates around Emily every day and night, we make a category mistake: Emily is not an object in the sky. Another example is "the Pythagorean theorem is blue": theorems do not have colors. "God is green" is a metaphor too, because God has no visible colors. It would be senseless to ask what kind of green should be attributed to God. Had "God has power" been a metaphor, there would be no difference between "God has power" and "God is green" and it would be senseless to ask what kind of power God has. It does make sense, though, to ask what kind of power God has, and there is a difference between these two statements. The reason for this is that "God has power" is no category mistake; power is not a visible entity or property that cannot be directly attributed to God. I am under the impression that Brueggemann and Rendtorff intuitively grasped this distinction between metaphorical and literal God-talk by interpreting concrete nouns in the Old Testament as metaphors but not all verbs, adjectives and abstract nouns which are applied to God (Brueggemann 1997:230-233, 247-248; Rendtorff 2001:181-185, 193).

In the remainder of this article, I shall try to describe briefly the characteristics of God implied by the metaphor of king. Although the metaphor of king also has implications for our relation with God and for the appropriate attitude and behavior towards God, the focus here will be on God. 


\section{God our King}

\subsection{Relationality}

Kingship is a relationship between God and us. This relationship is between persons, but it is not what we would normally call a personal relationship in which the one has value for the other because of what she or he is (Brümmer 1993:165, 166). Kingship is an office, a relationship of rights and duties. For modern people, there is a difference or even a contrast between personal and official identity. Although the phrase "my king" in the Psalms (Ps 5:3; 44:5; $68: 25 ; 74: 12 ; 84: 4)$ sounds rather personal and might be used to express a personal relationship in particular contexts, the metaphor of king is not the best way of expressing God's personal relationship with us. God's personal identity and God's personal relationship with us are better expressed by the proper names "YHWH" and "the Father of Jesus Christ".

Moreover, kingship is a hierarchical relationship. This is implied by the ultimate authority of the divine king. As king, God is "above" us and no one is "above" God. To put it differently: kingship is an asymmetric relationship: no human being can be the king of God; we cannot command God, nor can we judge God. In God's kingship, God is free and independent. The Old Testament witness shows that God can act independently of the kings of Israel and that God can use the kings of the world to realize God's purposes (Dietrich 1980:262; Mettinger 2005:136-142; Brueggemann 1997:239, 240). In addition, the coming of God's kingdom ultimately is not dependent on human agency. However, this independence is not absolute; it qualifies the relationship. God is independent in God's kingly relation with us. God's kingship is not a relation of possession; this king is no despot. Nor is God's kingship a manipulative relationship in which human beings are used as objects (as described by Brümmer 1993:158); God commands and wants God's people to freely obey God. As an official relationship it remains a mutual relation between persons in that the relation of the king to his people implies a corresponding relation of obedience of the people to their king. In sum, God's kingship is an asymmetric mutual relationship.

\subsection{Agency}

The relationship of God's kingship is not static, but dynamic: to be king is to rule. Four forms of agency in which God reigns can be distinguished on the basis of our exploration of God's kingship according to the Biblical witness. Firstly, God's rule implies that God wars against the enemies of God's people, because God wants to liberate the victims from evil - and, in God's justification of the sinner, it includes the doers of evil too - and give them ultimate peace and joy. This king is the liberator of his people. 
Secondly, God's rule implies the ordering of human relations in society in a just way (Jüngel 1998:45, 46), that is, which does justice to people, especially as it pertains to the weak and the poor, the "widow and the orphan". God orders society by commanding people and motivating and inspiring them to serve God's purposes. This king is the one who proclaims his law and writes it on the hearts of his people by his Spirit.

Thirdly, God's rule implies that God orders the events of history to achieve the ultimate goal God has determined for it: the kingdom of God (Barth 1950:186-198). In this sense, God controls history. This king is also the shepherd who leads his people in history to its future.

Lastly, at the end of history God will condemn evil and realize and manifest God's justice for all creatures. This king is the highest judge of his people.

The Biblical witness about God who liberates, commands, controls, and judges presupposes that God has the power to do so. This power-to is the capacity to perform these acts in human history and to assert his sovereign rule.

\subsection{The attribute of divine power}

As we have seen, God's power cannot be adequately understood if separated from God's authority. The power of God as king is precisely the power to exercise God's authority. This means that God's power is power-over, power over other powers and power over God's creatures (Van Gennep 1989:416421). This power-over is a different power to his power-to, God's capacity to act. This power-over becomes particularly clear in God's rule which presupposes beings that are liberated, commanded, controlled, and judged by God. Without the authority of the liberating God in which God's power-over is grounded, this power is misunderstood as despotism.

In addition, God's power should also be understood from God's ultimate purposes and goals: justice, peace, and love for all. God's power over the powers of evil and sin is revealed in the way God has fought against them and triumphed over them in the life, death and resurrection of God's Son Jesus Christ. The deepest word for both God's ultimate goal and for God's way of achieving it, is the love of God. This means that our understanding of God's power must be in accordance with God's love.

Modern people easily identify power with oppression and violence. Moreover, in modern times the phenomenon of power as such has become suspect because power is so often exercised arbitrarily and by means of manipulation, threat and coercion. If we identify power with arbitrariness, oppression, violence, manipulation, threat, or coercion, calling God powerful, 


\section{God our King}

would make a monster of God. Differently put: if we accept modern notions of power, we have to say that the loving Father of Jesus Christ can have no power.

On the other hand, the concept of a powerless God would contradict the Biblical witness about God's present kingship and God's coming kingdom. Fortunately, the modern definitions of power are far from self-evident. Power in general and the power of God in particular can be understood in better ways. Firstly, it should be noted that the exercise of authority and the right use of power are necessary conditions for communication between human beings in an order of justice and peace (Van Gennep 1989:404, 405). Secondly, it must be remembered that God's power is not quantitatively, but qualitatively different from human power (cf Van den Brink 1993:178). If we understand God's power quantitatively as an infinite amount of the force we find in physical reality and the influence we find in human society, we wrongly apply a zero-sum conception of power to God. This conceptualization implies that the more power one has, the less power others have, and vice versa. If we apply this conception of power to the relation between God and man, any power of God would threaten the power of human beings and vice versa (Van den Brink 1993:122-124; Markus 2004:301-302). God's power-over, though, does not destroy, but demands and creates free human obedience and cooperation. This shows that God's power is exercised on another level than that of the physical force or human influence. Apparently, God's power can cooperate with human power without diminishing it.

In order to further specify the power of God, our king, I distinguish five means by which power-over is realized:

1) moral influence;

2) coercion;

3) oppression;

4) physical force;

5) physical violence against people.

When we ask which of these are implied by God's power over other powers and over God's people, the following can be said on the basis of the Biblical witness about God's kingship and coming kingdom: God surely has influence over people through God's law and his Spirit, but God's command and inspiration do not coerce them, because God demands free obedience and wants to cooperate with them. Oppression is excluded, because God is no despot, but the liberator who wants the salvation of his people, and ultimately of mankind. The realization of God's coming kingdom will require a form of 
force just as the creation did in the beginning, but it is impossible for us to understand this creative force because the physical force we know is an element of created reality. It is doubtful whether God's ultimate victory over and God's judgment of the powers of evil will be possible without any form of violence against God's enemies (De Kruijf 2004:57, 58). In the meantime, the exercising of God's authority as king in human history is not violent because it is the rule of both the Father and the Son in the mode of the Spirit.

Eventually, God will defeat all the powers that war against God's kingship and God will be acknowledged as king by all God's creatures. In this way, God will create justice and peace for all and all will enjoy God's love.

\section{Works consulted}

Barr, J [1961] 1996. The semantics of Biblical language. London: SCM.

Barth, K 1937. Die Kirchliche Dogmatik, I/2. Zürich: Theologischer Verlag Zürich. Barth, K 1939. Die Kirchliche Dogmatik, II/1. Zürich: Theologischer Verlag Zürich. Barth, K 1950. Die Kirchliche Dogmatik, III/3. Zürich: Theologischer Verlag Zürich. Barth, K 1976. Das christliche Leben: Die Kirchliche Dogmatik, IV, 4, Fragmente aus dem Nachlass Vorlesungen 1959-1961. Drewes, H-A \& Jüngel, E (Hrsg). Zürich: Theologischer Verlag Zürich.

Berkhof, H [1973] 1993. Christelijk geloof: Een inleiding tot de geloofsleer. $7^{\mathrm{e}} \mathrm{dr}$. Nijkerk: Callenbach.

Brink van den, G 1993. Almighty God: A study of the doctrine of divine omnipotence. Kampen: Kok Pharos. (Studies in Philosophical Theology 7.)

Brueggemann, W 1997. Theology of the Old Testament: Testimony, dispute, advocacy. Minneapolis, MN: Fortress.

Brümmer, V 1993. The model of love: A study in philosophical theology. Cambridge: Cambridge University Press.

Buber, M 1936. Königtum Gottes. Berlin: Schocken.

Childs, B S [1992] 1996. Biblical theology of the Old and New Testaments. London: SCM.

De Kruijf, G G 2004. How violence disappeared from God, in Bakker, F L (ed), Rethinking ecumenism: Strategies for the $21^{\text {st }}$ Century. Zoetermeer: Meinema. (IIMO Research Publications 63.)

Dunn, J D G 1998. The theology of Paul the apostle. Edinburgh: T\&T Clark.

Dietrich, W 1980. Gott als König: Zur Frage nach der theologischen und politischen Legitimität religiöser Begriffsbildung. ZThK 77, 251-268.

Gennep van, F O 1989. De terugkeer van de verloren vader: Een theologisch essay over vaderschap en macht in cultuur en christendom. Baarn: Ten Have.

Härle, W 1999. Die Basilea-Verkündigung Jesu als implizite Gotteslehre, in Härle, W \& Preul, R (Hrsg), Reich Gottes, 11-30. Marburg: Elwert. (Marburger Jahrbuch Theologie XI.)

Jüngel, E 1972. Paulus und Jesus: Eine Untersuchung zur Präzisierung der Frage nach dem Ursprung der Christologie. 4. Auflage. Tübingen: Mohr.

Jüngel, E 1998. Das Evangelium von der Rechtfertigung des Gottlosen als Zentrum des christlichen Glaubens. Tübingen: Mohr. 


\section{God our King}

Ladd, G E 1962. The Kingdom of God - Reign or realm? JBL 81, 230-238.

Lindemann, A 1986. Herrschaft Gottes/Reich Gottes IV: Neues Testament und spätantikes Judentum, TRE 15, 196-218.

Markus, A 2004. Beyond finitude: God's transcendence and the meaning of life. Frankfurt am Main: Peter Lang. (Contributions to Philosophical Theology 11.)

McFague, S 1982. Metaphorical theology: Models of God in religious language. Philadelphia, PA: Fortess.

McFague, S 1987. Models of God: Theology for an ecological, nuclear age. London: SCM.

Mettinger, T N D [1987] 2005. In search of God: The meaning and message of the everlasting names. Philadelphia, PA: Fortress.

Mildenberger, F 1992. Biblische Dogmatik: Eine Biblische Theologie in dogmatischer Perspektive, Band 2: Ökonomie als Theologie. Stuttgart: Kohlhammer.

Miskotte, K H [1941] 1971. Bijbels abc. $3^{\mathrm{e}} \mathrm{dr}$. Baarn: Ten Have.

Moltmann, J 1995. Das Kommen Gottes: Christliche Eschatologie. Gütersloh: Chr. Kaiser/Gütersloher Verlagshaus.

Moltmann, J [1964] 1997. Theologie der Hoffnung: Untersuchungen zur Begründung und zu den Konsequenzen einer christlichen Eschatologie. 13. Auflage. Gütersloh: Chr. Kaiser/Gütersloher Verlagshaus. (Kaiser Taschenbücher 155.)

Noordmans, O [1949] 1979. Het koninkrijk der hemelen: Toelichting op de Heidelbergse Catechismus zondag 7-22. Verzamelde Werken II, 433-551. Kampen: Kok.

O'Neill, J C 1993. The Kingdom of God. NT 35, 130-141.

Rendtorff, R 2001. Theologie des Alten Testaments: Ein kanonischer Entwurf, Band 2: Thematische Entfaltung. Neukirchen: Neukirchener Verlag.

Ricoeur, P 1977. Entre philosophie et théologie II: nommer Dieu, in Ricoeur, P, Lectures 3: Aux frontiers de la philosophie. Paris: Seuil.

Schillebeeckx, E 1982. Jezus: Het verhaal van een levende. $9^{e} \mathrm{dr}$. Baarn: Nelissen.

Soskice, J M 1985. Metaphor and religious language. Oxford: Clarendon.

Theissen, G 2001. Die Religion der ersten Christen: Eine Theorie des Urchristentums. 2. Auflage. Gütersloh: Chr. Kaiser/Gütersloher Verlagshaus.

Van Huyssteen, J W 1997. Essays in postfoundationalist theology. Grand Rapids, MI: Eerdmans.

Van Ruler, A A [1974] 1974. De vervulling van de wet: Een dogmatische studie over de verhouding van openbaring en existentie. Nijkerk: Callenbach.

Von Rad, G [1933] 1964. s v melek and malkut in the OT. TDNTI, 565-571.

Zenger, E 1986. s v Herrschaft Gottes/Reich Gottes II; Altes Testament. TRE 15, 176-189. 